\title{
OPEN Impacts of parent material on distributions of potentially toxic elements in soils from Pearl River Delta in South China
}

\author{
Qingye Hou ${ }^{1}$, Zhongfang Yang ${ }^{1 凶}$, Tao Yu ${ }^{1}$, Yuanhang You ${ }^{2}$, Lei Dou ${ }^{3} \& \mathrm{Kuo} \mathrm{Li}^{4}$
}

Assessing the impacts of parent material on distributions of potentially toxic elements (PTEs) in soils has significant consequences in the apportionment of their sources. In this study, geochemical distributions and sources of PTEs in the soils developed in quaternary sediments and granite plutons of Pearl River Delta (PRD), South China, were investigated. The results indicate that there are systematic differences between the concentrations of oxides and PTEs in the soils developed in these two parent materials. The parent material predominantly determines the element distributions in the soils. The PTEs of the deep soils developed in quaternary sediments originated mainly from mafic, felsic, and carbonate sources materials as well as polymetallic deposits. For the deep soils developed in granite plutons, the element associations are governed mainly by their geochemical affinities and behaviors and the mineral compositions of granite plutons. Anthropogenic activities impact the features of the PTEs in the surface soils of PRD. However, superimposed regional-scale pollution was found to not hide the effect of the parent material on the distribution of PTEs in the surface soils.

Geochemical distributions, sources, and environmental effects of potentially toxic elements (PTEs) in soils have gained significant attention over several years ${ }^{1-5}$. The soils in alluvial or flood plain have been intensively used for agriculture because of their generally high fertility ${ }^{6}$, and the alluvial plains have also undergone industrialization and urbanization for a long time in view of their topography and transportation condition. Therefore, the sources and risk assessment of PTEs in soils of alluvial plain have become hot topics of recent studies ${ }^{7-11}$. A river delta forms when a river carrying suspended sediments reaches an ocean, from which an alluvial plain forms. The PTEs in fluvial sediments originate from various sources in the catchment area and are transported by the river water and sediments. Alluvial soils developed in quaternary fluvial sediments could inherit the original geochemical characteristics of fluvial sediments. The geochemical distributions of PTEs in alluvial soils depend on the regional lithology of drainage basin, historical floodplain topography, and anthropogenic activities.

Pearl River Delta (PRD) in South China has undergone rapid industrialization and urbanization and become a major manufacturing hub over the past three decades. The sources and environmental impact of PTEs in surface soils, sediments, and groundwater of PRD have been of concern in recent years ${ }^{12-17}$. Anthropogenic activities have been identified as the most significant sources of PTEs in the surface soils of PRD, such as electronics and electroplating industries ${ }^{12}$, agricultural non-point sources ${ }^{15}$, atmospheric deposition ${ }^{15}$, and so on. However, the results of the regional geochemical survey indicated that the geochemical distributions of PTEs in the soils of PRD seemed to be associated with underlying parent material instead of man-made pollution ${ }^{17}$. The surface and deep soils in the alluvial plain of Pearl River contain high concentrations of soil organic carbon (SOC), $\mathrm{TFe}_{2} \mathrm{O}_{3}$ (total $\mathrm{Fe}$, as $\mathrm{Fe}_{2} \mathrm{O}_{3}$ ), $\mathrm{Mn}, \mathrm{As}, \mathrm{Cd}, \mathrm{Co}, \mathrm{Cr}, \mathrm{Cu}, \mathrm{Ni}, \mathrm{Hg}, \mathrm{Pb}$, and $\mathrm{Zn}^{17}$. For example, the median values of $\mathrm{Mn}$, $\mathrm{Cd}, \mathrm{Cu}$ and $\mathrm{Hg}$ concentrations in surface soils in the alluvial plain of Pearl River are $483 \mathrm{mg} \mathrm{kg}{ }^{-1}, 228 \mu \mathrm{g} \mathrm{kg}^{-1}$, $33.78 \mathrm{mg} \mathrm{kg}^{-1}$ and $136 \mu \mathrm{g} \mathrm{kg}^{-1}$ respectively. However, the median values of them in surface soils developed in granite plutons are $247 \mathrm{mg} \mathrm{kg}^{-1}, 65 \mu \mathrm{g} \mathrm{kg}-1,6.95 \mathrm{mg} \mathrm{kg}^{-1}$ and $77 \mu \mathrm{g} \mathrm{kg}^{-1}$ respectively. Therefore, the sources of the high concentrations of PTEs in the soils of PRD still remains unclear.

The total concentrations of PTEs are not enough to assess any actually occurring adverse effects on the soil ecosystem. The mobility and bioavailability of PTEs in the soils depend on their total concentrations, specific

\footnotetext{
${ }^{1}$ School of Earth Sciences and Resources, China University of Geosciences, Beijing 100083, China. ${ }^{23 r d}$ Geological Team, Guangdong Geological Bureau, Shaoguan 512030, China. ${ }^{3}$ Guangdong Geological Bureau, Guangdong Geologic Survey Institute, Guangzhou 510080, China. ${ }^{4}$ Institute of Geophysical and Geochemical Exploration, Chinese Academy of Geological Sciences, Langfang 065000 , China. ${ }^{\circledR}$ email: yangzf@cugb.edu.cn
} 

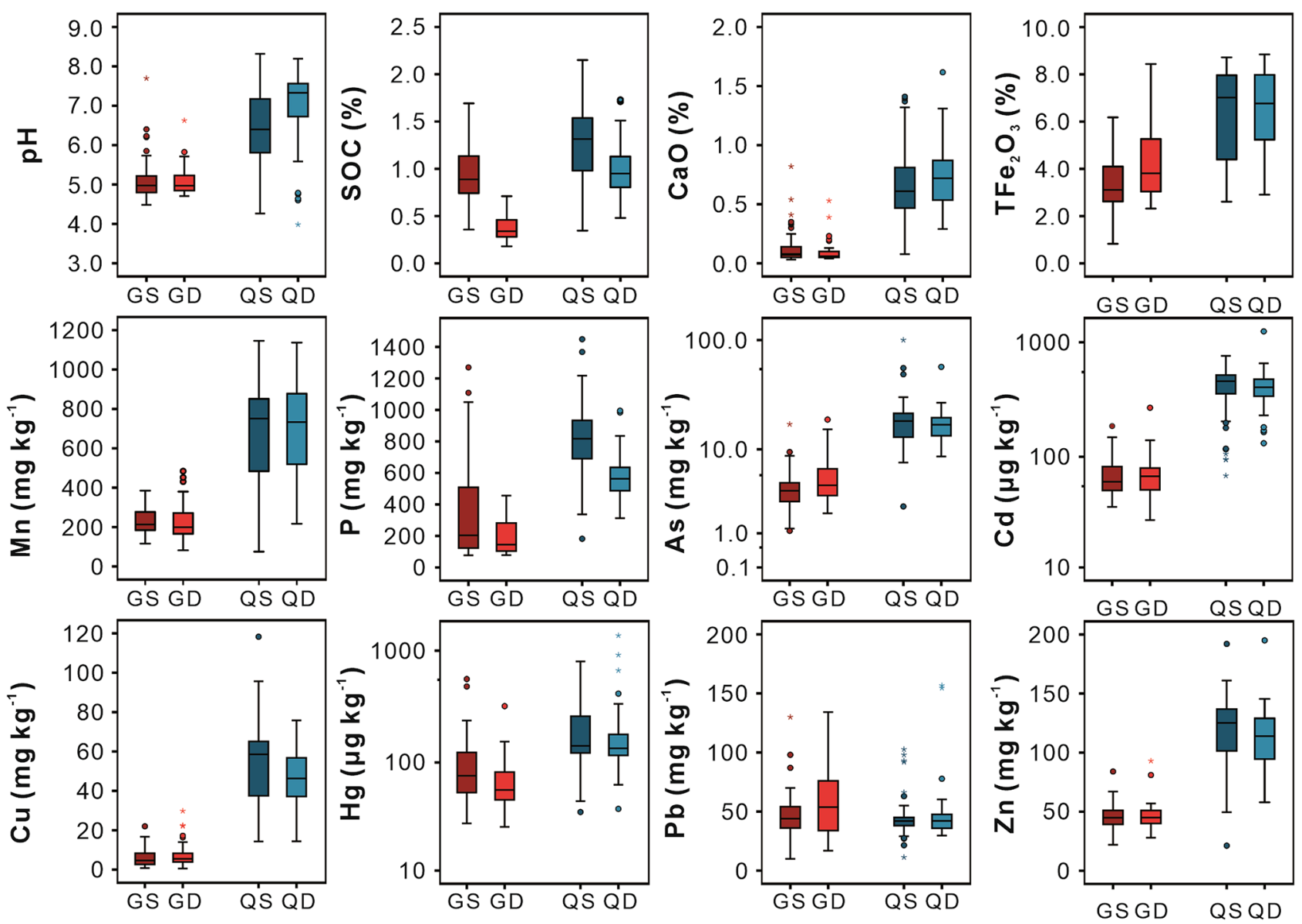

Figure 1. The Tukey boxplots of oxides and potential toxic elements of the surface and deep soils. QS and QD, the surface and deep soils developed in quaternary sediments; GS and GD, the surface and deep soils developed in granite plutons.

chemical form, binding state, metal properties, environmental factors, and soil properties ${ }^{18}$. Nevertheless, to our knowledge, whether there are differences in the mobility of PTEs in the soils developed in different parent materials has not been reported to date. Therefore, the assessment of the impacts of the parent material on the characteristics of PTEs in soils from an urbanization area deserves significant attention. It is also very useful to reevaluate the impact of human activities on the distributions of PTEs in the soils in these areas. In this study, we compared the geochemical characteristics of PTEs and the geochemical fractions of $\mathrm{Cd}$ and $\mathrm{Pb}$ in the soils developed in granite plutons and quaternary sediments in PRD. Our objectives were to (1) present the geochemical differences in the PTEs in surface soils $(0-20 \mathrm{~cm})$, deep soils $(180-200 \mathrm{~cm})$, and the soil vertical profiles developed in quaternary sediments and granite plutons in PRD, (2) discuss the factors affecting the distributions of PTEs, and (3) assess the major sources of PTEs in the soils from PRD.

\section{Results}

Element concentrations in surface and deep soils. The statistical summaries of each parameter as well as their skewness and kurtosis coefficients in the surface and deep soils can be found as Supplementary Tables S1, S2, S3, and S4 online.

There are systematic differences in the concentrations of oxides and PTEs between the soils developed in the two parent materials. The concentrations of SOC, oxides, and PTEs of the surface and deep soils developed in the quaternary sediments are significantly higher than those of the soils developed in granite plutons, except for $\mathrm{Pb}$ (Fig. 1). For example, the median values of the concentration of $\mathrm{Cd}$ in the deep soils developed in the quaternary sediments and in granite plutons are $405 \mu \mathrm{g} \mathrm{kg}^{-1}$ (see Supplementary Table S2 online) and $67 \mu \mathrm{gg}^{-1}$ (see Supplementary Table S4 online), respectively.

From a comparison with the composition of the upper continental crust (UCC) ${ }^{19}$ (see Supplementary Table S5 online), it is found that the concentrations of $\mathrm{As}, \mathrm{Cd}, \mathrm{Cu}, \mathrm{Hg}, \mathrm{Pb}$, and $\mathrm{Zn}$ in the soils developed in the quaternary sediments are higher than the UCC abundances, and the concentrations of $\mathrm{Cr}$ and Ni are slightly lower than the UCC abundances (Fig. 2a). In the soils developed in granite plutons, the median values of the concentrations of $\mathrm{As}, \mathrm{Cd}, \mathrm{Cr}, \mathrm{Cu}, \mathrm{Ni}$ and $\mathrm{Zn}$ are lower than the UCC abundances (Fig. 2a). Normalized to the background values of China soils (BVCS) ${ }^{20}$ (Fig. 2b), all the PTEs in the soils developed in the quaternary sediments exhibit enriched features. Only the concentrations of $\mathrm{Hg}$ and $\mathrm{Pb}$ in the soils developed in granite plutons are slightly 

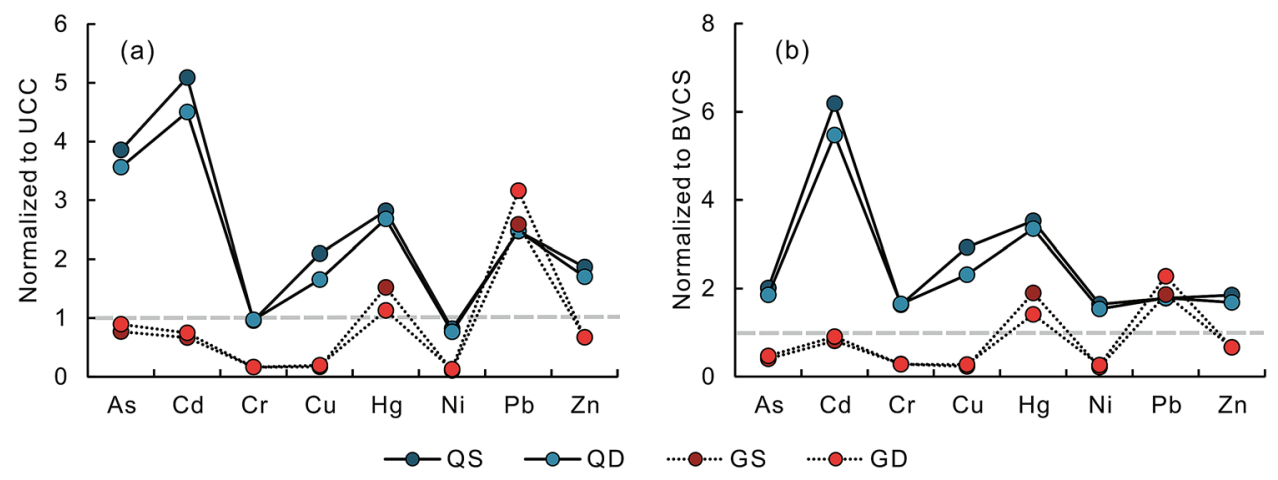

Figure 2. Normalized patterns for the potential toxic element contents in the soils. (a), upper continental crust (UCC) normalized data are from ${ }^{19}$; (b), background values of China soils (BVCS) normalized data are from ${ }^{20}$; QS and QD, the surface and deep soils developed in quaternary sediments; GS and GD, the surface and deep soils developed in granite plutons.

higher than the BVCS. Compared with the risk-screening values for soil contamination of agricultural land ${ }^{21}$, the concentrations of $\mathrm{Cd}$ and As in the deep soils developed in the quaternary sediments exceed the risk-screening values by $11.4 \%$ and $7.6 \%$, respectively. The concentrations of $\mathrm{Cd}, \mathrm{As}, \mathrm{Hg}$, and $\mathrm{Pb}$ in the surface soils developed in the quaternary sediments exceed the risk-screening values, and their rates reach $38.9 \%, 7.8 \%, 8.9 \%$, and $1.1 \%$ respectively. All the PTEs in the soils developed in granite plutons do not exceed the risk-screening values. Further, the median values of the concentrations of PTEs in the deep soils developed in the quaternary sediments of PRD (see Supplementary Table S2 online) are significantly higher than those in the deep soils of other alluvial plains in China such as in the Yangtze ${ }^{22}$, Yellow ${ }^{23}$, and Haihe River Deltas ${ }^{24}$ (see Supplementary Table S5 online).

PTEs in soil vertical profiles. The medians and ranges of oxides and PTEs in the soil vertical profiles obtained in this investigation can be found as Supplementary Tables S6 and S7 online. The vertical distributions of the PTEs in the soil profiles developed in granite plutons are presented in Fig. 3a,b. The concentration of As is higher in the surface horizons and lower in the deeper horizons. The concentrations of $\mathrm{Cd}, \mathrm{Cu}, \mathrm{Hg}, \mathrm{Pb}$, and $\mathrm{Zn}$ vary within a wide range. The vertical distributions of the PTEs in the soil profiles developed in the quaternary sediments are presented in Fig. 3c,d,e. The PTEs exhibit slightly higher concentrations in the surface soils than in the deep soils. The concentrations of PTEs in the soil vertical profiles of the quaternary sediments are significantly higher than those in the soil vertical profiles of granite plutons (see Supplementary Fig. S1 online). The median values of the concentrations of $\mathrm{As}, \mathrm{Cd}, \mathrm{Cu}, \mathrm{Hg}, \mathrm{Pb}$, and $\mathrm{Zn}$ in the soil vertical profiles of the quaternary sediments are as high as $6.2,15.2,3.3,1.6,1.4$, and 3.0 times, respectively, their median values in the soil vertical profiles of granite plutons.

Geochemical fractions of $\mathbf{C d}$ and $\mathrm{Pb}$ in soil vertical profiles. The contributions of the different geochemical fractions of $\mathrm{Cd}$ and $\mathrm{Pb}$ in the soil vertical profiles are depicted in Figs. 4 and 5. The median values of the geochemical fractions of $\mathrm{Cd}$ and $\mathrm{Pb}$ for each soil profile can be found as Supplementary Table S8 online.

The studied soils demonstrate a large variation in the distribution of $\mathrm{Cd}$ among the different geochemical fractions. The relative significance of the Cd geochemical fractions in the soil vertical profiles developed in the quaternary sediments follows the order: F2 $>$ F4 $>$ F5 $>$ F3 $\approx$ F7 $>$ F6 $>$ F1 (Fig. 4). The relative significance of $\mathrm{Cd}$ geochemical fractions in the soil vertical profiles developed in granite plutons is significantly different. It follows the order: F4 $>$ F7 $>$ F6 $>$ F2 $\approx$ F5 $>$ F3 $>$ F1 (Fig. 5). All Cd geochemical fractions indicate significantly higher median values in the soil vertical profiles developed in quaternary sediments than in those developed in granite plutons (see Supplementary Table S8 online). The mobile fractions ( $E F 1-F 2)$ of Cd have median values of approximately $119.5-215.7 \mu \mathrm{g} \mathrm{kg}^{-1}$ in the soil vertical profiles developed in quaternary sediments and $3.8-4.4 \mu \mathrm{g} \mathrm{kg}^{-1}$ in the soil vertical profiles developed in granite plutons. Meanwhile, the geochemical fractions of $\mathrm{Cd}$ in quaternary boreholes with depths of 23.2-47.0 $\mathrm{m}$ in PRD also indicate that Cd has very high mobile fractions ${ }^{25}$. High mobile (and thus ecotoxicologically relevant) amounts of Cd have been demonstrated in other alluvial soils as well ${ }^{8}$. Therefore, Cd poses a potentially higher environmental risk and mobility in soils developed in quaternary sediments than those in granite plutons.

The main geochemical fractions of $\mathrm{Pb}$ are residual and $\mathrm{Fe}-\mathrm{Mn}$ oxides fractions. The percentages of the residual and $\mathrm{Fe}-\mathrm{Mn}$ oxides fractions in the soil vertical profiles developed in quaternary sediments and granite plutons are $83.30 \%$ and $50.59 \%$, respectively. The concentration of $\mathrm{Pb}$ in the ion-exchangeable fraction has a higher proportion in the soil vertical profiles developed in granite plutons (19.50\%) than those in the soil vertical profiles developed in quaternary sediments (4.89\%). The median value of total concentration of $\mathrm{Pb}$ in the soil vertical profiles developed in granite plutons $\left(65.99 \mathrm{mg} \mathrm{kg}^{-1}\right)$ is higher than in the soil vertical profiles developed in quaternary sediments $\left(41.42 \mathrm{mg} \mathrm{kg}^{-1}\right)$. Therefore, $\mathrm{Pb}$ in the former has a potentially higher environmental risk and mobility than in the latter. 

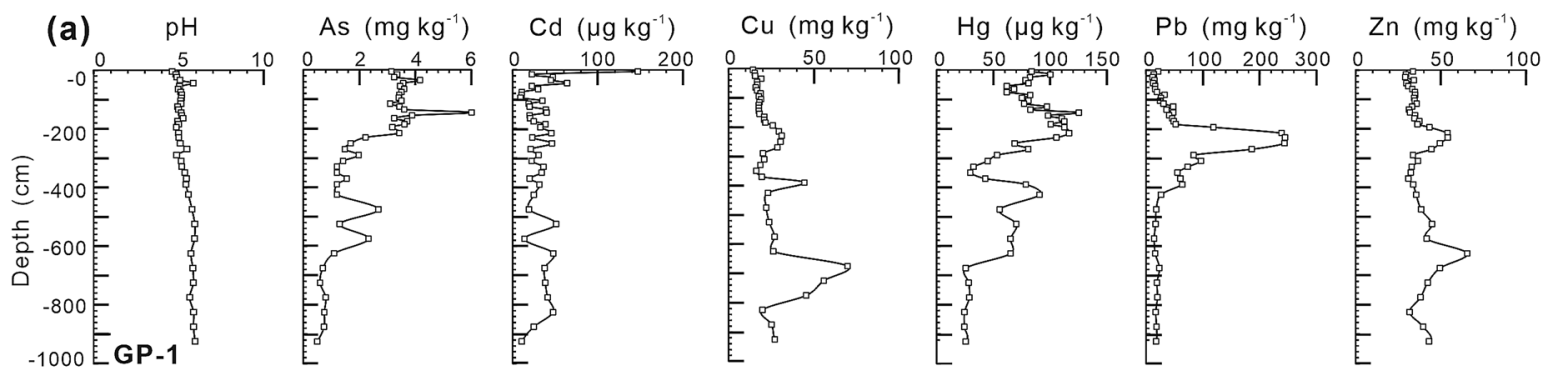

(b)

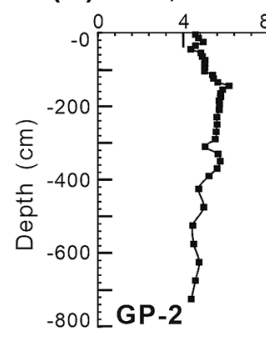

As $\left(\mathrm{mg} \mathrm{kg}^{-1}\right)$
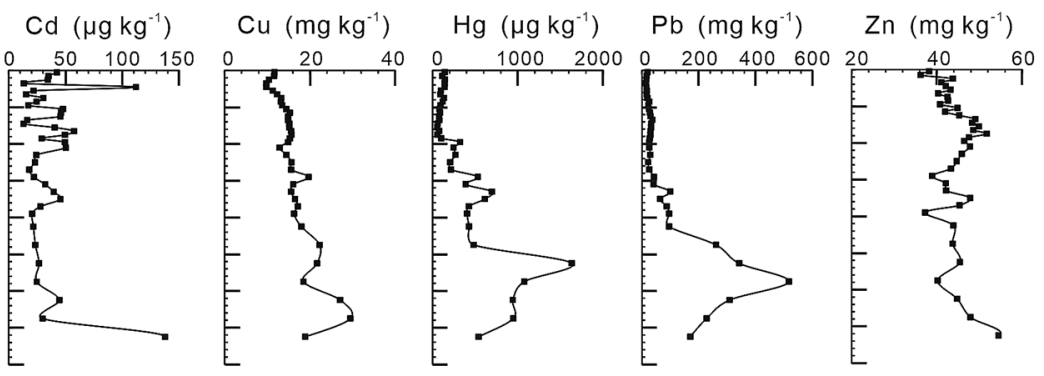

(c)
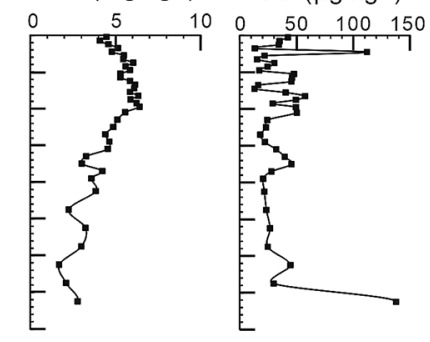

$\mathrm{Cu}\left(\mathrm{mg} \mathrm{kg}^{-1}\right)$
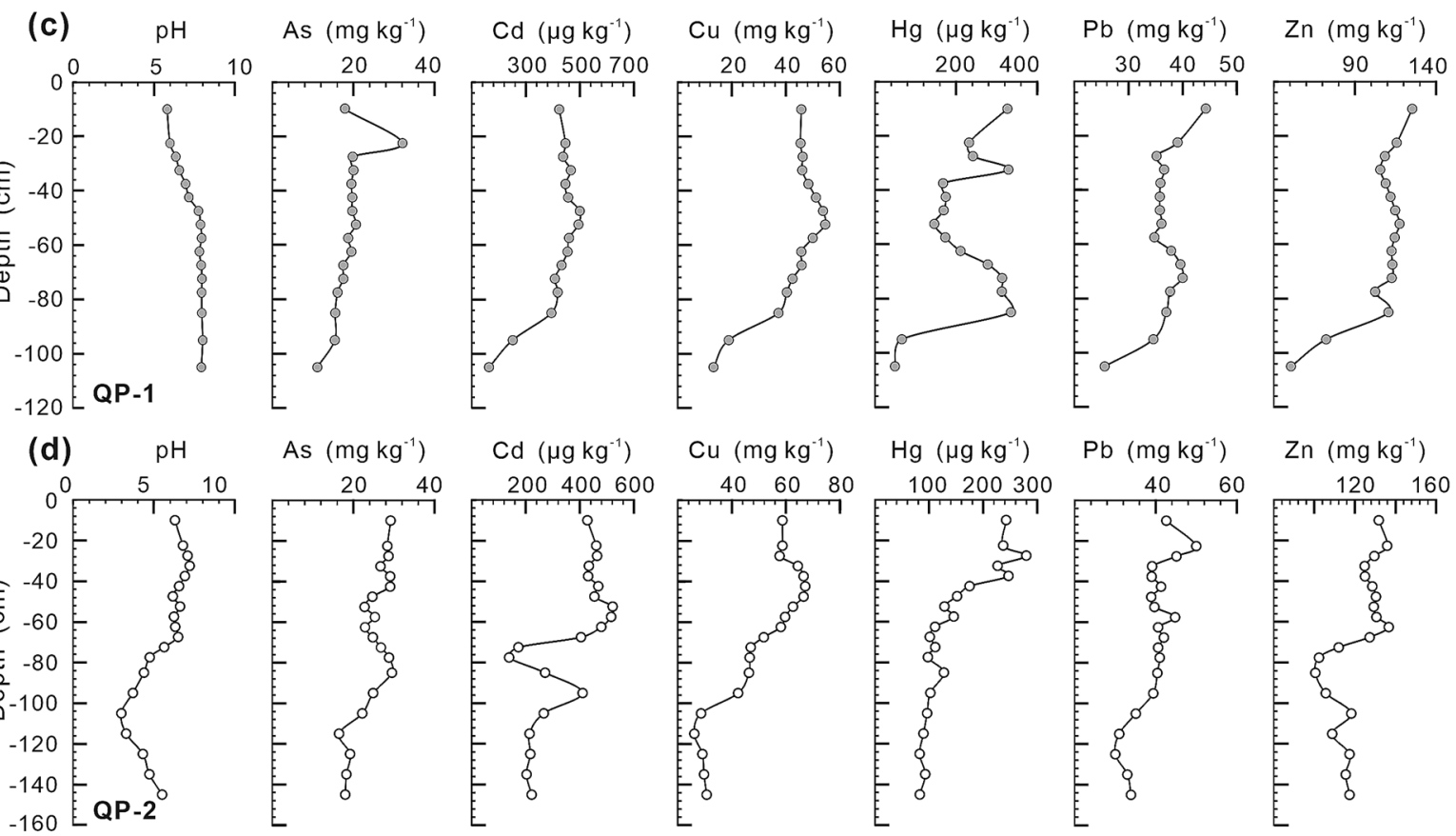

As $\left(\mathrm{mg} \mathrm{kg}^{-1}\right)$
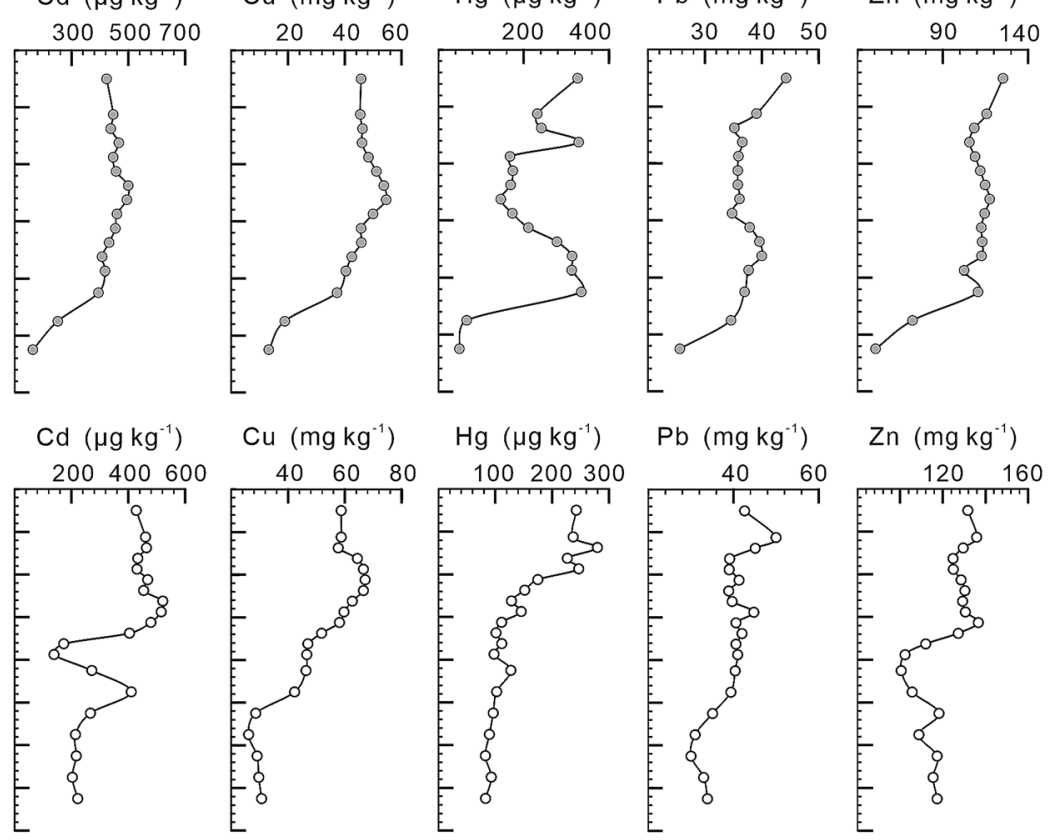

(e)
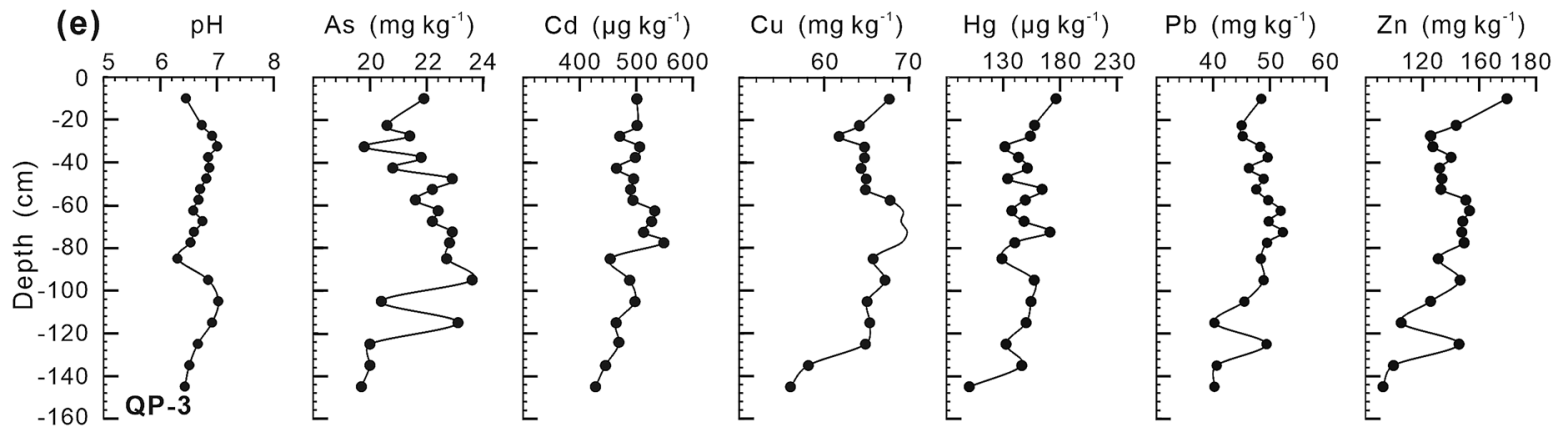

Figure 3. Vertical distributions of $\mathrm{pH}$ and potential toxic elements concentrations in the soil profiles developed in granite plutons and quaternary sediments. GP, soil profiles in granite plutons; QP, soil profiles in quaternary sediments. 


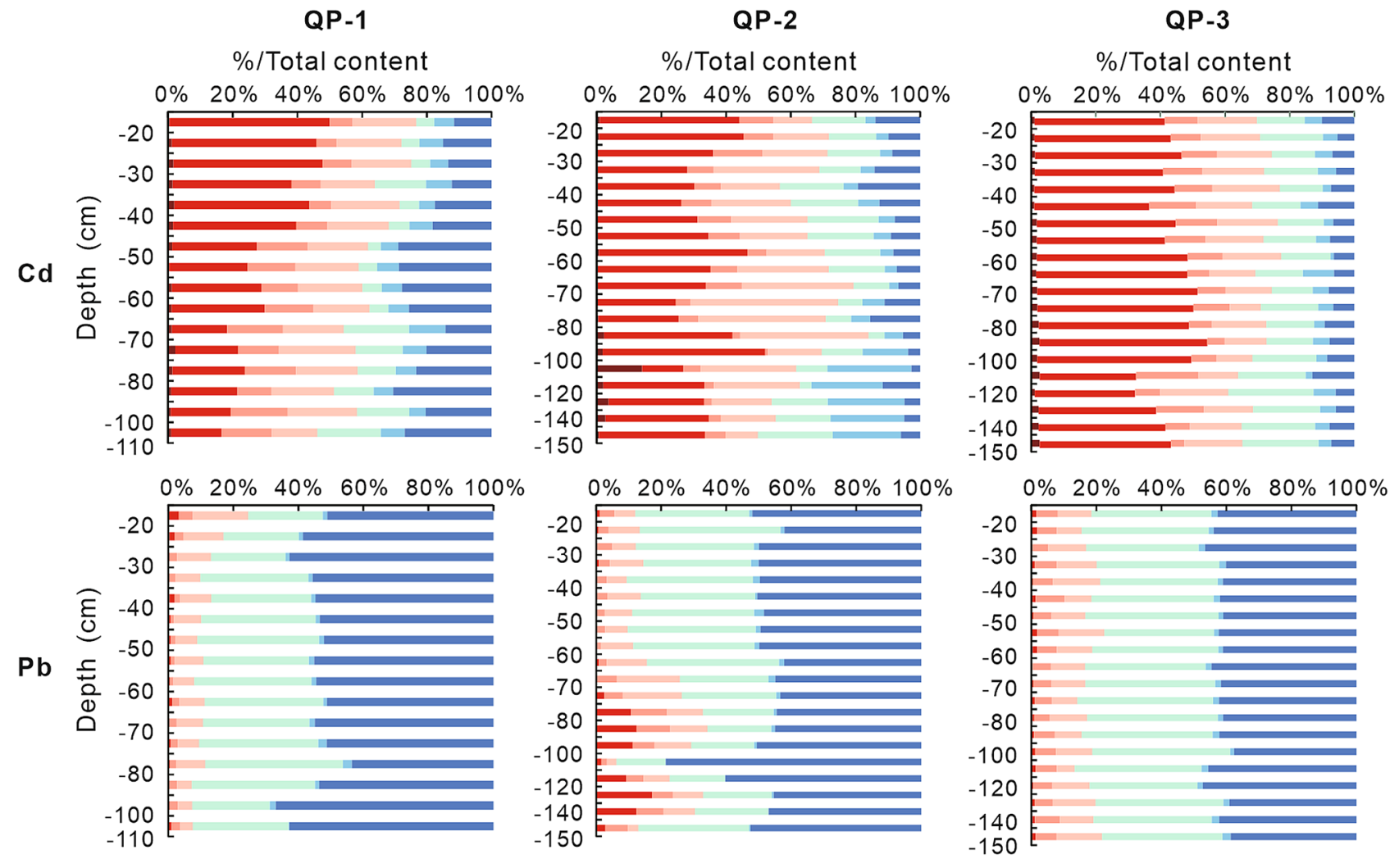

F1, Soluble fraction

F2, lon exchangeable fraction

F3, Easily mobilizable fraction

\title{
F4, Labile OM fraction
}

F5, Fe-Mn oxides fraction

F6, Refractory OM fraction

\section{F7, Residual fraction}

Figure 4. Vertical distributions of $\mathrm{Cd}$ and $\mathrm{Pb}$ in various geochemical fractions in the soil profiles developed in quaternary sediments.

\begin{abstract}
Discussion
Factors affecting distributions of PTEs. Figure 6a,b depicts biplots (PC1-PC2) for the principal component scores and loadings for the surface and deep soils developed in quaternary sediments. The first three principal components of the surface soils account for $61.3 \%$. Magnesium, $\mathrm{Fe}, \mathrm{Mn}, \mathrm{Ni}, \mathrm{Cr}$, and $\mathrm{Cu}$ are grouped along the + $\mathrm{PC} 1$ axis. Silicon, $\mathrm{Na}, \mathrm{K}, \mathrm{Pb}, \mathrm{P}, \mathrm{As}$, and $\mathrm{Hg}$ concentrate along the - $\mathrm{PC1}$ axis. The $\mathrm{PC}$ scores along the PC1 axis define a contrast between the mafic (+ scores) and felsic (-scores) source materials. The $\mathrm{pH}, \mathrm{Ca}$, and $\mathrm{Cd}$ are associated along the $+\mathrm{PC} 2$ axis (Fig. 6a). The biplot of Fig. $6 \mathrm{~b}$ for deep soils depicts similar patterns in terms of the relationships of the elements with each other. The first three principal components for the deep soils account for $60.7 \%$. Magnesium, $\mathrm{Fe}, \mathrm{Mn}, \mathrm{Ni}, \mathrm{Cr}$, and $\mathrm{Cu}$ are grouped along the $+\mathrm{PC} 1$ axis, probably representing mafic source material (Fig. 6a,b). Silicon, K, Pb, and $\mathrm{Hg}$ associations reflect felsic source material. The group of $\mathrm{pH}, \mathrm{Ca}$, and $\mathrm{Cd}$ probably represents carbonate sources.

Figure $6 c$, d presents biplots (PC1-PC2) for the principal components scores and loadings for the surface and deep soils developed in granite plutons. The first three principal components account for $61.7 \%$ and $60.8 \%$, respectively. The elements of the surface soils concentrate in five groups: (1) $\mathrm{Fe}, \mathrm{As}, \mathrm{Cr}$, and $\mathrm{Ni}$ (+ PC1); (2) SOC, $\mathrm{N}$, P, and $\mathrm{Hg}$ (+ PC2); (3) pH, Ca, Cd, and $\mathrm{Cu}(-\mathrm{PC} 1)$; (4) Na, K, Pb, and Mn (- PC1, - PC2); (5) Si, Al, Mg, and $\mathrm{Zn}(+\mathrm{PC} 1,-\mathrm{PC} 2)$ (Fig. $6 \mathrm{c}$ ). The biplot for the deep soils displays different patterns in terms of the relationships of the elements with each other (Fig. 6d). The elements cluster in four groups: (1) $\mathrm{Fe}, \mathrm{P}, \mathrm{As}, \mathrm{Cr}, \mathrm{Ni}$, and $\mathrm{Cu}$ (+ PC1); (2) Si, Al, Zn (+ PC2, - PC1); (3) K, Na, Cd, and Pb (- PC1), (4) Ca, Mg, and pH (- PC2) (Fig. 6d). For the deep soils, the $+\mathrm{PC1}$ axis in Fig. $6 \mathrm{~d}$ indicates a chalcophile association of $\mathrm{Fe}, \mathrm{As}, \mathrm{Cr}, \mathrm{Ni}$, and $\mathrm{Cu}$. Cadmium and $\mathrm{Pb}$ are grouped with $\mathrm{K}$ and $\mathrm{Na}$, probably representing feldspars. For the surface soils, $\mathrm{Cd}$ and $\mathrm{Cu}$ are clustered with $\mathrm{pH}$ and $\mathrm{Ca}$, probably representing pedogenetic processes. The SOC, N, P, and $\mathrm{Hg}$ association represents organic materials.

Total concentrations of $\mathrm{Cd}$ and $\mathrm{Pb}$ and the percentages of their geochemical fractions are correlated with several soil variables in the soil profiles developed in the quaternary sediments (see Supplementary Table S9 online). However, there are almost no correlations among them in the soil profiles developed in granite plutons (see Supplementary Table S10 online). In the soil profiles developed in quaternary sediments, total Cd concentration indicates significant correlations with $\mathrm{pH}, \mathrm{P}, \mathrm{TFe}_{2} \mathrm{O}_{3}, \mathrm{CaO}, \mathrm{Zn}$, and $\mathrm{Mn}$. F1 of Cd is negatively correlated with
\end{abstract}




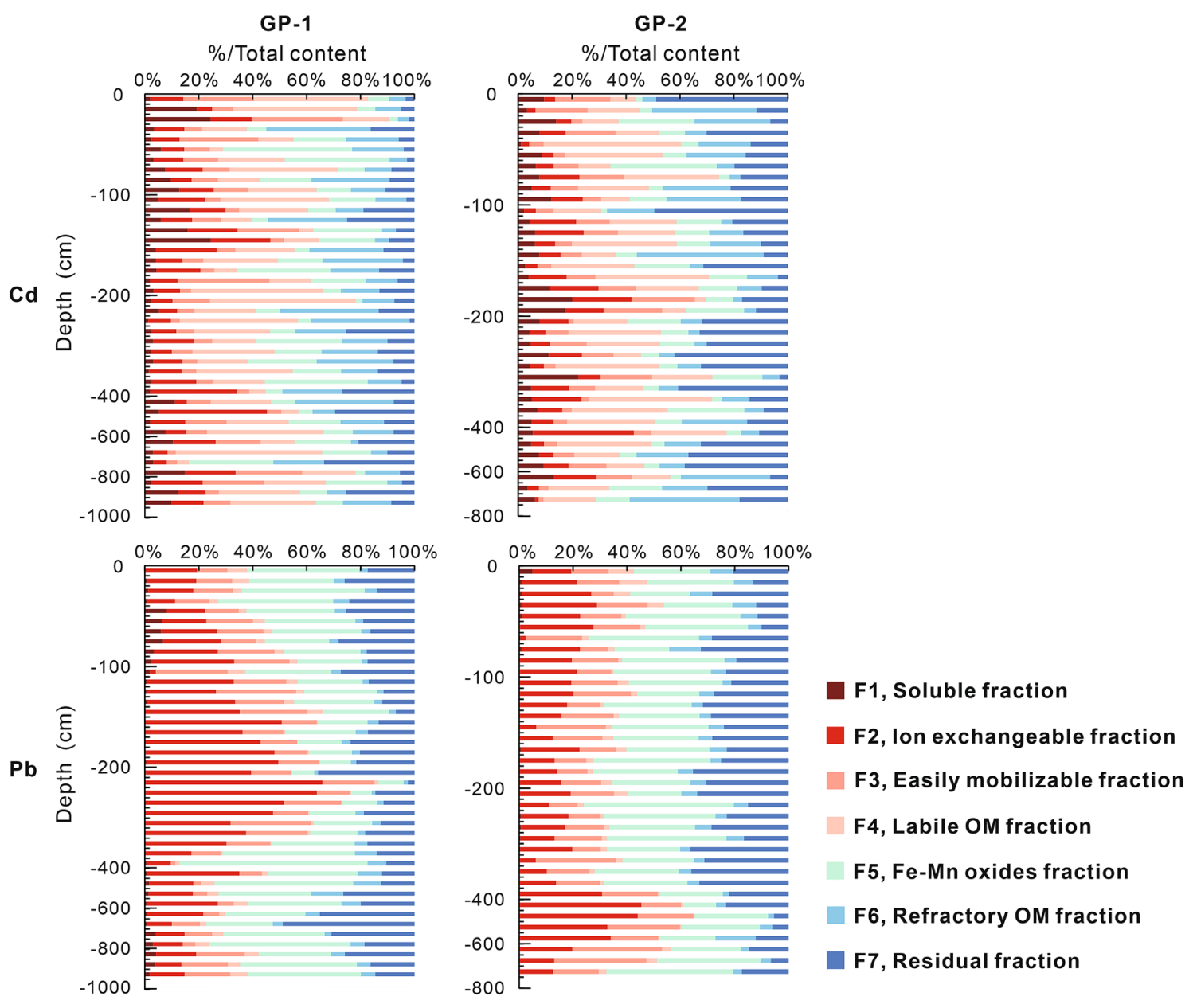

Figure 5. Vertical distributions of $\mathrm{Cd}$ and $\mathrm{Pb}$ in various geochemical fractions in the soil profiles developed in granite plutons.

pH. F2 of Cd indicates a strong positive relationship with SOC, N, $\mathrm{P}, \mathrm{Al}_{2} \mathrm{O}_{3}, \mathrm{TFe}_{2} \mathrm{O}_{3}, \mathrm{Zn}$, and the total concentration of $\mathrm{Cd}$. Therefore, the potentially toxicological effect of $\mathrm{Cd}$ release is remarkable when the concentrations of nutrient elements (SOC, N, P) in the soils of the study area are high. F3 of Cd is positively correlated with $\mathrm{pH}$ and $\mathrm{CaO}$. This fraction of $\mathrm{Cd}$ could easily be released with decreasing $\mathrm{pH}$ value. The total concentration of $\mathrm{Pb}$ indicates significant correlations with the soil variables. $\mathrm{F} 1$ of $\mathrm{Pb}$ indicates positive relationships with $\mathrm{pH}, \mathrm{P}$, and $\mathrm{CaO}$. However, $\mathrm{F} 2$ of $\mathrm{Pb}$ is negatively correlated with these variables. Therefore, F1 and $\mathrm{F} 2$ of $\mathrm{Pb}$ could be transformable. $\mathrm{F} 3$ of $\mathrm{Pb}$ is positively correlated with $\mathrm{SOC}$, whereas it is negatively correlated with $\mathrm{pH}$ and $\mathrm{Mn}$. $\mathrm{F} 5$ of $\mathrm{Pb}$ positively correlates with $\mathrm{Mn}$. $\mathrm{Pb}$ may evolve to more crystalline and stable structures of manganese hydrous oxides and become immobile. Alternatively, $\mathrm{Pb}$ could be released into the soil solution by the reductive dissolution of manganese oxyhydroxides ${ }^{8}$.

Major sources of PTEs in deep soils. It is impossible that the features of PTEs in the deep soils are affected by man-made pollution. Therefore, the systematic geochemical differences in PTEs of the deep soils developed between the quaternary sediments and granite plutons suggest that the parent material governs mainly the elemental compositions of the soils.

Other evidences are obtained from the distributions and geochemical fractions of PTEs in the soil vertical profiles or quaternary boreholes. The concentrations of PTEs in the soil vertical profiles developed in quaternary sediments are also significantly higher than in the soil vertical profiles developed in granite plutons (see Supplementary Figure S1 online). There is also a significant difference between the geochemical fractions of Cd and $\mathrm{Pb}$ in the soil vertical profiles developed in these two parent materials. The clay layer of a representative quaternary borehole, whose depth is between 12.7 and $26.60 \mathrm{~m}$, has average concentrations of $10.8 \mathrm{mg} \mathrm{kg}^{-1}$, $831 \mu \mathrm{g} \mathrm{kg}^{-1}$, and $102 \mu \mathrm{g} \mathrm{kg}^{-1}$ for As, Cd, and $\mathrm{Hg}$, respectively ${ }^{25}$, which are higher than their median values in the deep soils developed in granite plutons (see Supplementary Table S4 online). Comparing these values with those in other alluvial plains of China, the concentrations of PTEs in the deep soils from PRD are significantly higher (see Supplementary Tables S2 and S5 online). Consequently, the PTEs in the deep soils from PRD maybe represent the geochemical characteristics of their parent material. Therefore, we place further emphasis on the major sources of PTEs in the deep soils developed in quaternary sediments. 

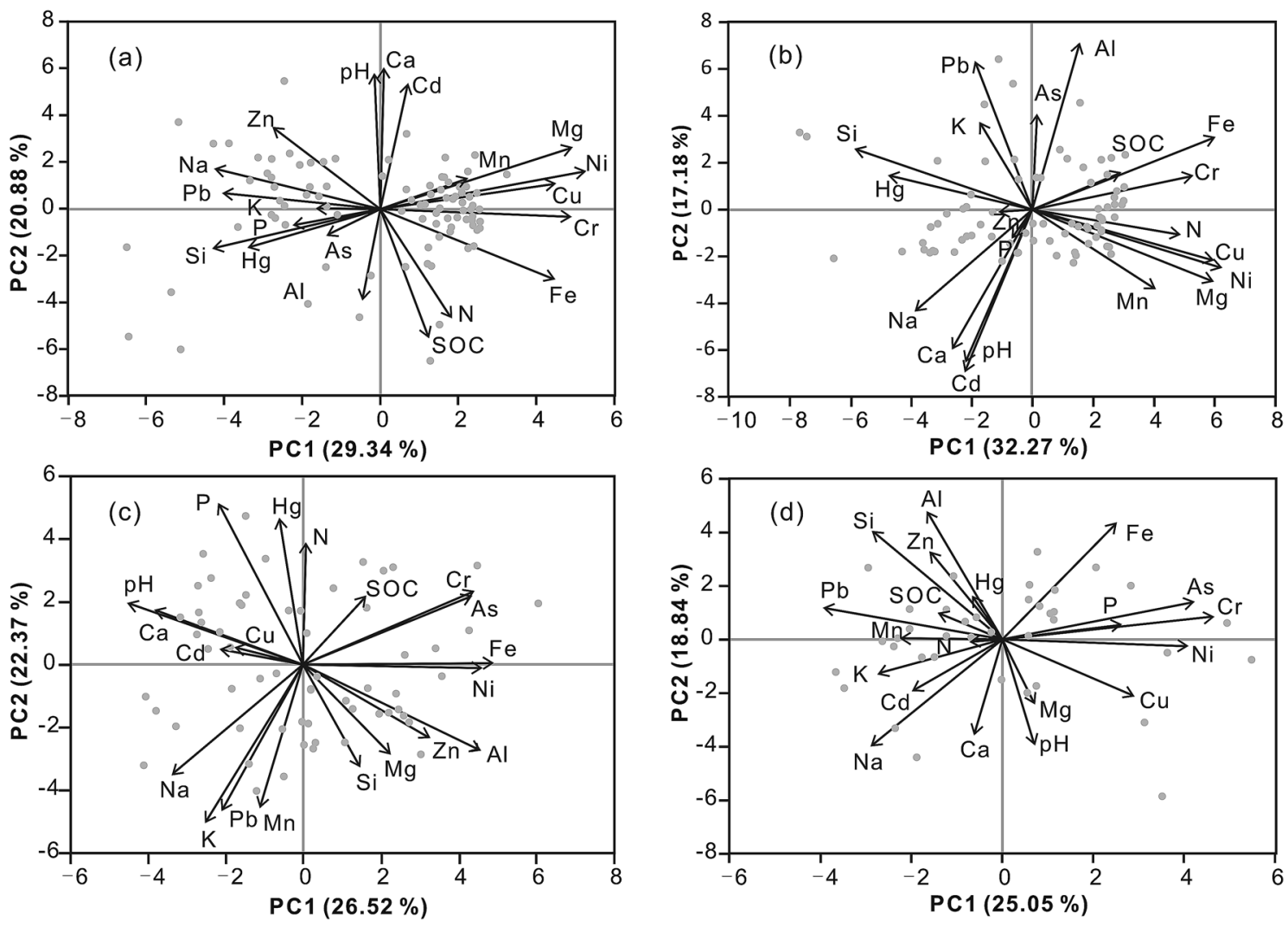

Figure 6. Biplots showing the results of principal components analysis (PCA) for soil geochemical data based on a centered log-ratio transformation (clr). (a, b), Biplots of PC1 and PC2 for the surface and deep soils developed in quaternary sediments respectively; (c, d), biplots of PC1 and PC2 for the surface and deep soils developed in granite plutons respectively.

The PTEs in the deep soils or their parent material were transported by the river water and sediments and originated from various sources in the catchment area at different geological times. The $\mathrm{Pb}$ isotopic characteristics of quaternary sediments indicate that the alluvial sediments in PRD had stable sources ${ }^{26}$. The main factors determining the high concentrations of PTEs in the deep soils were source rocks and mineral deposits in the river catchment, particle compositions, and sedimentary environment. The vertical distributions of trace elements in the sediment cores from major rivers in east China indicate that the high concentrations of As, Cd, $\mathrm{Hg}$, $\mathrm{Mn}, \mathrm{Mo}, \mathrm{Pb}$, and $\mathrm{Zn}$ in most southern rivers were predominantly governed by the geological setting, regional mineralization, and geochemical landscape ${ }^{27}$. The concentrations of PTEs in water and suspended particulate matter in the Pearl River and its branches are higher than those in other rivers of China ${ }^{28}$. Numerous carbonate rocks (or karst areas) and super-large or large polymetallic deposits exist in the upper reaches of the West River and North River, which provide large amounts of PTEs for PRD.

Karst areas can affect the concentrations of PTEs in the soils of the Pearl River alluvial plains in the lower reaches in two possible ways. Carbonate rocks are enriched in Cd. Otavite-calcite solid solutions could grow at the (104) cleavage surface of single crystal calcite or dolomite and form Cd-rich carbonate ${ }^{29,30}$. Approximately $5.1 \times 10^{5} \mathrm{~km}^{2}$ of exposed and outcropped carbonate rock in Southwest China is one of the largest continuous karst areas in the world ${ }^{31}$, and is mainly located in most tributaries of the West River. In the chemical weathering of carbonate rock, $\mathrm{Ca}, \mathrm{Mg}$ and $\mathrm{Cd}$ may be released into the river system, migrating to and depositing in the downstream alluvial plain area. Anomalous Cd and other PTEs have been observed in the soils developed from carbonate rock from a typical karst region in China, which is located in the upper reaches of $\mathrm{PRD}^{32}$. The range of concentration of Cd in the soils is $200-5620 \mu \mathrm{g} \mathrm{kg}{ }^{-132}$. Anomalous $\mathrm{Cd}$ and other PTEs have also been reported in the soils developed in calcareous rocks from other areas of the world ${ }^{33-35}$. The karst areas of southwest China have experienced severe soil erosion ${ }^{36,37}$. Therefore, soil erosion via riverine inputs could be the other main source of PTEs.

In the natural weathering, mining, and smelting process of polymetallic deposits, a high volume of acid mine drainage rich in PTEs is produced ${ }^{38}$. Several super-large or large polymetallic deposits exit in the upper reaches of PRD, such as the Dabaoshan polymetallic deposit, Fankou Pb-Zn deposit, and Dachang Sn-polymetallic deposit. The chemical weathering of the sulfide minerals in these deposits is very intense owing to abundant rainfall and subtropical climate. For example, the Dabaoshan polymetallic deposit located in the upper reaches of the North River includes stratiform siderite orebodies, gossan formed by weathering processes, stratiform $\mathrm{Cu}-\mathrm{Pb}-\mathrm{Zn}$ orebodies, porphyry-type $\mathrm{Mo}-\mathrm{W}$, and skarn-type $\mathrm{Mo}-\mathrm{W}^{39}$. A large amount of PTEs were released into the environment when the sulfide minerals were oxidized into gossan. Meanwhile, soil erosion in these mine 

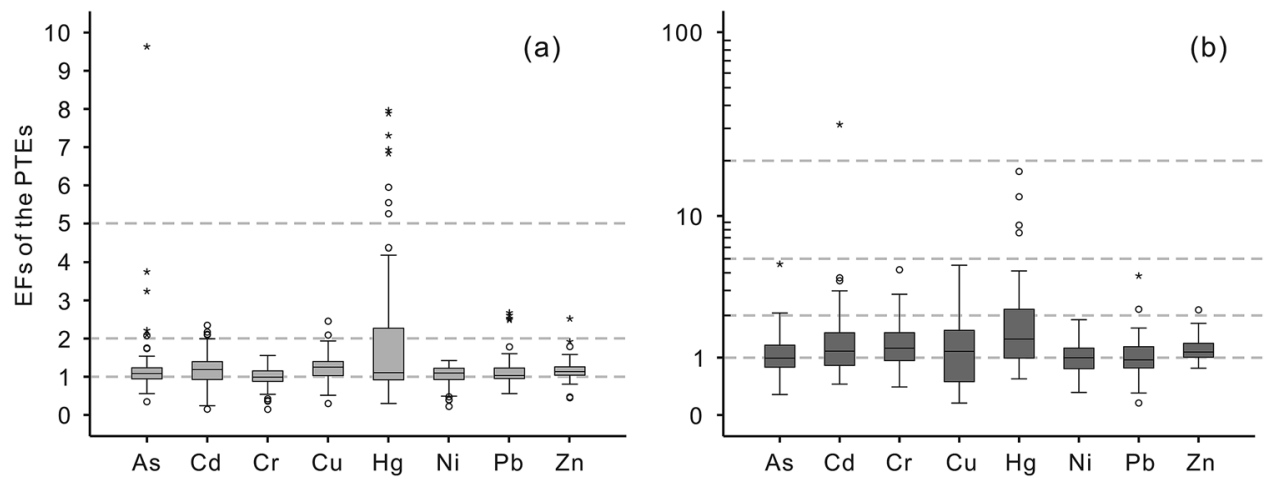

Figure 7. The Tukey boxplots of enrichment factors (EFs) of the potential toxic elements of the surface soils. (a) the surface soils developed in quaternary sediments; (b) the surface soils developed in granite plutons.

areas has also been very severe ${ }^{40}$. The average values of PTEs in the sediment cores of the North River are the highest among the major rivers in east China ${ }^{28}$. Therefore, the PTEs released by chemical weathering and erosion of polymetallic deposits over time could be transported by the rivers to PRD. These polymetallic deposits have been mined for several years. Therefore, contamination by PTEs in the soils or sediments of these mines is also grave $^{41-43}$. The concentrations of PTEs in the sediments and soils along the river are also very high ${ }^{44,45}$. The PTEs released during the mining and smelting processes could have induced severe surface soil and sediment pollution.

Major sources of PTEs in surface soils. It is generally believed that the PTEs in the surface soils of economically developed areas are affected by human activities. All the surface soils in this study were collected while avoiding point source pollution. Systematic differences exist in the PTEs between the surface soils developed in the quaternary sediments and granite plutons. The differences are similar to those in the deep soils and the soil vertical profiles (Figs. 1, 2, and 3). Therefore, the parent material is the most significant factor governing the concentrations of PTEs in the surface soils.

The concentrations of $\mathrm{As}, \mathrm{Cd}, \mathrm{Cu}$, and $\mathrm{Zn}$ in the surface soils are higher than in the deep soils developed in quaternary sediments (Fig. 1). The concentration of $\mathrm{Hg}$ in the surface soils is higher than that in the deep soils developed in these two parent materials (Fig. 1). Therefore, it appears that human activities have impacted the concentrations of PTEs in the surface soils.

As depicted in Fig. 7, Hg exhibits more significant pollution than the other PTEs. For the surface soils developed in quaternary sediments, the median values of EFs for PTEs are ranked in a decreasing order: $\mathrm{Cu}(1.25)>\mathrm{Cd}$ $(1.19)>\mathrm{Zn}(1.13)>\mathrm{Hg}(1.11)>\mathrm{Ni}(1.10)>\mathrm{As}(1.08)>\mathrm{Pb}(1.03)>\mathrm{Cr}(0.99)$. Cd, $\mathrm{Zn}$, and $\mathrm{Pb}$ are in slight pollution, and $\mathrm{Cr}$ and $\mathrm{Ni}$ are in slight or no pollution. Some surface soils display $\mathrm{As}, \mathrm{Cd}, \mathrm{Cu}, \mathrm{Pb}$, and $\mathrm{Zn}$ in moderate pollution (Fig. 7a). In detail, the EF value of $\mathrm{Hg}$ ranges from 0.3 to 8.0, in which approximately $9 \%$ of the samples are in significant pollution. For the surface soils developed in granite plutons, the median values of EFs for PTEs are ranked in a decreasing order: $\mathrm{Hg}(1.50)>\mathrm{Cr}(1.24)>\mathrm{Cd}, \mathrm{Cu}(1.16)>\mathrm{Zn}(1.14)>\mathrm{Ni}(1.00)>\mathrm{As}(0.99)>\mathrm{Pb}(0.94)$. Most surface soils exhibit slight pollution (Fig. $7 \mathrm{~b}$ ). The EF value of $\mathrm{Hg}$ ranges from 0.6 to 17.8 , with a few samples exceeding 5 (significant pollution). No surface soil samples with the EFs of all the PTEs less than 1 exist, which suggests that anthropogenic activities have significantly impacted the features of the PTEs in the surface soils of PRD. The study of the $\mathrm{Pb}$ isotopic and elemental composition of the soils collected from PRD also indicated that $\mathrm{Pb}$ in the soils originated from the natural background, automobile exhaust, and industrial pollution ${ }^{46}$.

\section{Conclusions}

In this study, the geochemical distributions and sources of PTEs in the soils developed in the quaternary sediments and granite plutons of PRD were discussed. The concentrations of SOC, oxides and PTEs in the surface soils, deep soils, and soil vertical profiles developed in the quaternary sediments are higher than in the soils developed in granite plutons. Significant differences also exist in the $\mathrm{Cd}$ and $\mathrm{Pb}$ geochemical fractions and their controlling factors between the soil vertical profiles developed in these two parent materials. These systematic geochemical differences suggest that the parent material predominantly determines the element distributions of the soils. The PTEs of the deep soils developed in quaternary sediments originated mainly from mafic, felsic, and carbonate source materials as well as polymetallic deposits. For the deep soils developed in granite plutons, the elemental associations are governed mainly by their geochemical affinities and behaviors and the mineral compositions of granite plutons. Anthropogenic activities have impacted the features of the PTEs in the surface soils of PRD. However, superimposed regional-scale pollution did not cover the impact of parent material on the distribution of PTEs of the surface soils.

\section{Materials and methods}

Study area. Pearl River Delta (PRD) is located from $112^{\circ} 00^{\prime} \mathrm{E}$ to $115^{\circ} 25^{\prime} \mathrm{E}$ and $22^{\circ} 30^{\prime} \mathrm{N}$ to $23^{\circ} 45^{\prime} \mathrm{N}$, which is an economic zone in the Guangdong Province, South China. PRD covers an area of about 54,764 square kilometers with a population of 59.98 million $^{47}$. It lies within the typical subtropical climate regime with an annual 


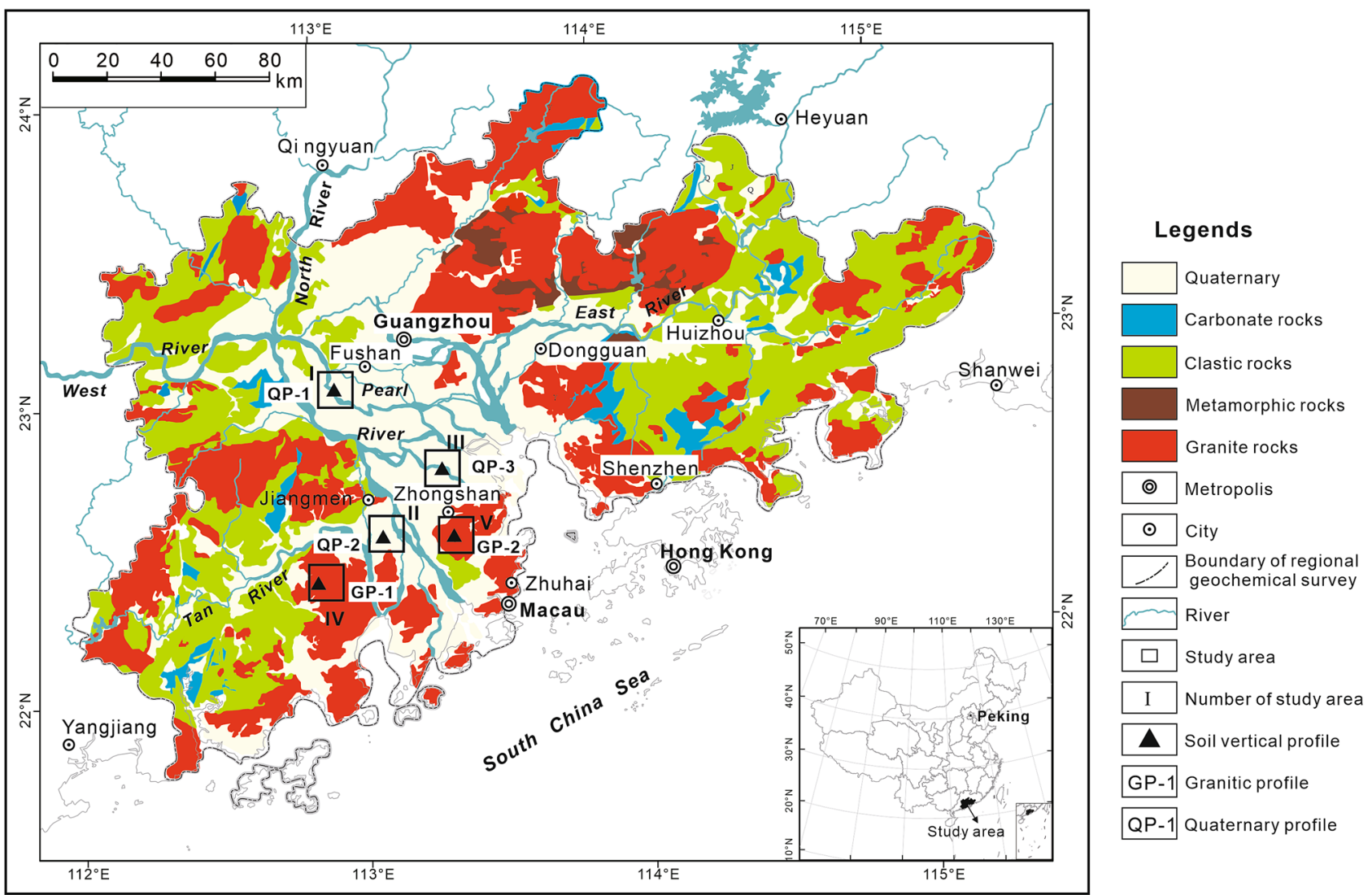

Figure 8. Sampling location and simplified lithological map of Pearl River Delta, South China. Lithological map are modified from ${ }^{17}$. The map was generated with software CorelDRAW Graphics Suite X3 (https://www. corel.com/en/old-versions/coreldraw-x3/).

temperature of $21-22^{\circ} \mathrm{C}$ and total annual rainfall of $1600-2000 \mathrm{~mm}$. The delta was formed by sediments deposited at the mouth of the Pearl River by the West River, North River, East River, and their tributaries. The shape of the Pearl River delta region is triangular. Approximately, one-fifth of the delta is dotted with granitic plutons and hill platforms composed of metamorphic rocks, sandstones, and shales ${ }^{48}$ (Fig. 8). It includes the big cities of Guangzhou, Zhuhai, Shenzhen, and so on. The sown area of grain crops in PRD is 6453 square kilometers ${ }^{47}$. PRD has undergone rapid industrialization and urbanization during the past three decades. The number of industrial enterprises whose annual principal business revenue are 20 million yuan or above is $32,202^{47}$. There are several metal smelting and calendering industries, plastic products industries, paper products industries, pharmaceutical manufacturing industries, petroleum processing industries etc ${ }^{47}$. The volume of industrial dust emission and solid wastes produced were 107 thousand tons and 23.95 million tons respectively in $2016^{47}$.

Sampling. Surface soils, deep soils and soil vertical profiles were collected from fiver study areas in PRD representing the soils developed in the quaternary sediments and granite plutons respectively (Fig. 8). Study areas numbered I, III and III are located in the distribution area of quaternary sediments. Study areas numbered IV and $\mathrm{V}$ are located in the distribution area of granite plutons surrounded by quaternary sediments. Soil vertical profiles numbered QP-1, QP-2 and QP-3 were taken from soils developed in the quaternary sediments, while profiles numbered GP-1 and GP-2 from soils developed in the granite plutons.

Surface soils at depths of $0-20 \mathrm{~cm}$ were collected at a density of $1 \mathrm{sample} / \mathrm{km}^{2}$ and deep soils $(150-180 \mathrm{~cm})$ were collected at a density of 1 sample $/ 4 \mathrm{~km}^{2}$. The surface soil samples were composited from 3 to 5 subsamples collected within $50 \mathrm{~m}$ of the sampling site. They were never collected from the sites near known point contaminated sources. In addition, no sample was collected at the time of fertilizing. Samples from $4 \mathrm{~km}^{2}$ for surface soils and $16 \mathrm{~km}^{2}$ for deep soils were composited for chemical analysis. Sites for soil vertical profiles were chosen based on a geologic lithological map in an attempt to represent the parent materials (quaternary sediments and granite plutons). The soil vertical profile samples were collected from pits by avoiding evidently disturbed or contaminated ground. They had no apparent layered structure. Thus, the samples were collected at various intervals. For soil vertical profiles developed in quaternary sediments, the surface soils were collected at depths of 0-20 cm. Other samples were collected at increments of $5 \mathrm{~cm}$ from $20 \mathrm{~cm}$ up to a depth of $80 \mathrm{~cm}$ and at increments of $10 \mathrm{~cm}$ at lower depths. For soil vertical profiles developed in granite plutons, samples were taken at increments of $10 \mathrm{~cm}$ from $0 \mathrm{~m}$ up to a depth of $2 \mathrm{~m}$, at increments $20 \mathrm{~cm}$ from $2 \mathrm{~m}$ up to a depth of $4 \mathrm{~m}$, and at increments of $50 \mathrm{~cm}$ at lower depths. 
All the sampling positions were pinpointed by means of the global positioning system (GPS). Visible plant detritus and any rock fragments were removed manually from the soil samples. After air-drying, the samples were crumbled using a wooden hammer, sieved to pass a 20 mesh $(<0.84 \mathrm{~mm})$ Nylon sieve, and further processed with a -200 mesh $(<0.074 \mathrm{~mm})$ for analysis ${ }^{49}$.

Chemical analysis. Geochemical data about the surface and deep soils were provided by the Guangdong Geological Bureau, People's Republic of China. All the data met the chemical analysis quality requirements of the national multipurpose regional geochemical survey in China ${ }^{17}$. The $\mathrm{pH}$, SOC, oxides, and PTEs of the soils in the vertical profiles were analyzed at the Hefei Mineral Resources Supervision and Testing Center, the Ministry of Land and Resources, People's Republic of China. The samples were pelletized and determined by wavelength dispersive X-ray fluorescence spectrometry PANALITICA AXIOS PW4400 for $\mathrm{SiO}_{2}, \mathrm{Al}_{2} \mathrm{O}_{3}, \mathrm{TFe}_{2} \mathrm{O}_{3}, \mathrm{MgO}, \mathrm{CaO}$, $\mathrm{Na}_{2} \mathrm{O}$ and $\mathrm{K}_{2} \mathrm{O}$. Calibrations were conducted using certified reference materials, and $\alpha$ correction was applied to correct for matrix interferences. For an analysis of the concentrations of PTEs, soil samples were digested using a mixture of $\mathrm{HClO}_{4}, \mathrm{HNO}_{3}$, and $\mathrm{HF}$ in Teflon tubes. The residue was then dissolved with aqua regia, and the supernatant was pipetted and diluted with $\mathrm{HNO}_{3}(3 \%)$. Arsenic and $\mathrm{Hg}$ were tested using atomic fluorescence spectrometry (AFS3100, Hai Guang, Inc., China). Cadmium, $\mathrm{Cr}, \mathrm{Cu}, \mathrm{Ni}, \mathrm{Pb}$, and $\mathrm{Zn}$ were tested using inductively coupled plasma mass spectrometry (ICAP-7400, Thermo Fisher Scientific, USA). The concentration of SOC was determined by wet oxidation in an acid dichromate solution, followed by back titration of the remaining dichromate using a ferrous ammonium sulfate solution ${ }^{50}$. The soil $\mathrm{pH}$ was measured with carbon dioxidefree water $(1: 2.5, \mathrm{w} / \mathrm{w})^{51}$ using a $\mathrm{pH}$ meter (PHS-3CF, Chuangfa, Inc., China). The measurement of nitrogen (N) was conducted with a Perkin Elmer 2400 series II CHNS/O analyzer.

The soil samples were sequentially extracted to determine seven fractions of $\mathrm{Cd}$ and $\mathrm{Pb}^{52,53}$. Briefly, $2.5 \mathrm{~g}$ of soil sample (100 mesh) and $25 \mathrm{~mL}$ of extracting agent were shaken for $30 \mathrm{~min}$ at $25^{\circ} \mathrm{C}$. The samples were centrifuged at $4000 \times \mathrm{g}$ for $20 \mathrm{~min}$ and filtered. The extracting agents and their operationally defined fractions can be found as Supplementary Table S11 online. The elements were sequentially fractionated into seven fractions as follows: F1 - soluble fraction, F2 - ion exchangeable fraction, F3-easily mobilizable fraction, F4-labile organic matter (OM) fraction, F5-Fe-Mn oxides fraction, F6 - refractory OM fraction, and F7-residual fraction.

The element concentrations in the digests and extracts were measured using inductively coupled plasmaatomic emission spectroscopy (ICP-AES) (X-SERIES II, Thermo Fisher Scientific, USA). Total digestion was performed on the samples as an internal check.

Quality control. Standard reference and replicate samples were used to monitor the trueness, repeatability, accuracy, and precision. The detection limits and allowance of accuracy and precision for routine analysis were discussed in details ${ }^{49}$. The analytical accuracy of the concentrations of the soil elements was controlled by the national standard material GSS02-GSS26. Coded samples were added to control the precision of the analytical data. The accuracy and precision of the elemental analyses of all samples met the quality requirements. To guarantee very high quality of the achieved results, the sum of each element extracted in the seven-step sequential extraction ( $\Sigma \mathrm{F} 1-\mathrm{F} 7)$ was compared with the results obtained by a separate aqua regia digestion as follows:

$$
\text { Recovery }=\frac{\mathrm{C}_{\text {sum }}-\mathrm{C}_{\text {total }}}{\mathrm{C}_{\text {total }}} \times 100 \%
$$

where $\mathrm{C}_{\text {sum }}$ is the sum of each element extracted in the seven-step sequential extraction and $\mathrm{C}_{\text {total }}$ is the concentration obtained by a separate aqua regia digestion.

In all measurements, the concentrations of the elements in the extracts were measured eight times, and analyses of standard reference samples were routinely included for quality control. The considered soil geochemical fractions of element results represent the arithmetic means of duplicate samples. The maximum relative standard deviation between replicates was less than $20 \%$.

Data processing. Geochemical data are a classic example of compositional (closed) data, and the element concentrations depend on each other ${ }^{54,55}$. This is significant for correlation analysis, for which the data must be appropriately log-ratio transformed ${ }^{56}$. The concentrations of the soil elements were adjusted using a centered log-ratio (clr) transformation ${ }^{56-58}$, which overcomes the "closure problem" produced by compositional data.

The $c l r$ transformation is defined as:

$$
\operatorname{cl}(x)=\left[\ln \frac{x_{1}}{g(x)} \ln \frac{x_{2}}{g(x)} \ldots \ln \frac{x_{D}}{g(x)}\right],
$$

where $g(x)=\left[x_{1} \cdot x_{2} \ldots \cdot x_{D}\right]^{1 / D}$ is the geometric mean of the composition $x$.

Robust compositional biplots were generated to better visualize the element distributions and quantify the main principal components. The scores represent the structure of the compositional data in the Euclidian space based on the variance and covariance matrices. Moreover, they display the association structure of the dataset. The variables are represented by rays (or vectors) drawn from the center of the plot, whose lengths are proportional to the amount of their explained variance (communality). The interpretation of the plots depends on the loading (the length of rays) structures and, in further details, on the approximate links between the rays and samples and the distances between the vertices and their directions ${ }^{59}$.

The median values of PTEs in the deep soils from PRD are considered as local background values, we can use the enrichment factor (EF) to quantify the extent of pollution caused by PTEs in the surface soils. The EF is calculated as follows: 


$$
\mathrm{EF}=\frac{[\mathrm{x} / \mathrm{R}]_{\text {sample }}}{[\mathrm{x} / \mathrm{R}]_{\text {background }}}
$$

where $[x / R]_{\text {sample }}$ and $[x / R]_{\text {background }}$ are the concentration ratios of the PTE and normalizer in the surface and deep soils, respectively. The conservative elements widely used for normalization include $\mathrm{Ti}, \mathrm{Al}, \mathrm{Fe}, \mathrm{Co}$, and $\mathrm{Sc}^{60,61}$, and $\mathrm{Al}$ was selected as the reference in this study. The median values of the concentrations of elements in deep soils (see Supplementary Tables S2 and S4 online) were used as the normalizers. The EF value is always classified into several grades, as follows: $\mathrm{EF}<1$, no pollution; $1<\mathrm{EF}<2$, slight pollution; $2<\mathrm{EF}<5$, moderate pollution; $5<\mathrm{EF}<20$, significant pollution; $\mathrm{EF}>20$, severe pollution $^{62}$.

Received: 23 April 2020; Accepted: 22 September 2020

Published online: 15 October 2020

\section{References}

1. Belzile, N. \& Chen, Y. Thallium in the environment: a critical review focused on natural waters, soils, sediments and airborne particles. Appl. Geochem. 84, 218-243 (2017).

2. Kubier, A., Wilkin, R. T. \& Pichler, T. Cadmium in soils and groundwater: a review. Appl. Geochem. 108, 104388 (2019).

3. Wilson, S. C., Lockwood, P. V., Ashley, P. M. \& Tighe, M. The Chemistry and behaviour of antimony in the soil environment with comparisons to arsenic: a critical review. Environ. Pollut. 158, 1169-1181 (2010).

4. White, S. J. O., Keach, C. \& Hemond, H. F. Atmospheric deposition of indium in the northeastern United States: flux and historical trends. Environ. Sci. Technol. 49, 12705-12713 (2015).

5. Zhou, Y., Niu, L., Liu, K., Yin, S. \& Liu, W. Arsenic in agricultural soils across China: distribution pattern, accumulation trend, influencing factors, and risk assessment. Sci. Total Environ. 616-617, 156-163 (2018).

6. Du Laing, G., Rinklebe, J., Vandecasteele, B., Meers, E. \& Tack, F. M. G. Trace metal behaviour in estuarine and riverine floodplain soils and sediments: a review. Sci. Total Environ. 407, 3972-3985 (2009).

7. Grygar, T. \& Popelka, J. Revisiting geochemical methods of distinguishing natural concentrations and pollution by risk elements in fluvial sediments. J. Geochem. Explor. 170, 39-57 (2016).

8. Schulz-Zunkel, C. \& Krüger, F. Trace metal dynamics in floodplain soils of the River Elbe: a review. J. Environ. Qual. 38, 1349-1362 (2009).

9. Bianchini, G., Natali, C., Giuseppe, D. D. \& Beccaluva, L. Heavy metals in soils and sedimentary deposits of the Padanian Plain (Ferrara, Northern Italy): characterisation and biomonitoring. J. Soils Sediments 12, 1145-1153 (2012).

10. Šajn, R., Halamić, J., Peh, Z., Galović, L. \& Alijagić, J. Assessment of the natural and anthropogenic sources of chemical elements in alluvial soils from the Drava River using multivariate statistical methods. J. Geochem. Explor. 110, 278-289 (2011).

11. $\mathrm{Hu}, \mathrm{B}$. et al. Spatio-temporal variation and source changes of potentially toxic elements in soil on a typical plain of the Yangtze River Delta, China (2002-2012) https://doi.org/10.1016/j.jenvman.2020.110943 (2020).

12. Bai, J. \& Liu, X. Heavy metal pollution in surface soils of Pearl River Delta, China. Environ. Monit. Assess. 186, 8051-8061 (2014).

13. Cheung, K., Poon, B. H. T., Lan, C. Y. \& Wong, M. H. Assessment of metal and nutrient concentrations in river water and sediment collected from the cities in the Pearl River Delta, South China. Chemosphere 52, 1431-1440 (2003).

14. Hu, Y. \& Cheng, H. Application of stochastic models in identification and apportionment of heavy metal pollution sources in the surface soils of a large-scale region. Environ. Sci. Technol. 47, 3752-3760 (2013).

15. Han, Z. et al. Occurrence and source identification of heavy metals in the alluvial soils of Pearl River Delta region, south China (in Chinese with English abstract), China. Environ. Sci. 38(9), 3455-3463 (2018).

16. Dou, L., Du, H., Huang, Y., Lai, Q. \& You, Y. Main research achievements of agro-geological and eco-geochemical research in Pearl River Delta Economic Zone, Guangdong Province, China (in Chinese with English abstract). Geol. Surv. China 2, 47-55 (2015).

17. Dou, L., Du, H., You, Y. \& Lai, Q. Eco-geochemical survey and assessment in Pearl River Delta Economic zone, Guangdong Province, China (in Chinese with English abstract). Geoscience 28, 915-927 (2014).

18. Shaheen, S. \& Rinklebe, J. Geochemical fractions of chromium, copper, and zinc and their vertical distribution in floodplain soil vertical profiles along the Central Elbe River, Germany. Geoderma 228-229, 142-159 (2014).

19. Rudnick, R. L. \& Gao, S. Composition of the continental crust. InTreatise on Geochemistry, V. 4.01 (Holland, H. D. \& Turekian, K. K. eds) 4-5 (Elsevier, Amsterdam, 2014).

20. China National Environmental Monitoring Centre. Elemental Background Values of China Soils (in Chinese) (China Environmental Science Press, Beijing, 1990).

21. Ministry of Ecology and Environment of the People's Republic of China. Soil Environmental Quality-Risk Control Standard for Soil Contamination of Agricultural Land (GB 15618-2018) (China Environmental Science Press, Beijing, 2018).

22. Chen, G. et al. Soil geochemical baselines of the Yangtze River Delta and their significances (in Chinese with English abstract). Geoscience 22, 1041-1048 (2008).

23. Pang, X., Li, X., Wang, B., Zeng, X. \& Chen, L. Geochemical characteristics of soil in Alluvial Plain of the Yellow River in Shandong Province (in Chinese with English abstract). Land Resour. Shangdong Prov. 24, 26-29 (2008).

24. Cao, F. et al. Soil geochemical baseline and environmental background values in northern Haihe Plain, China (in Chinese with English abstract). Geol. Bull. China 29, 1215-1219 (2010).

25. Tang, Z., Hou, Q., You, Y., Yang, Z. \& Li, K. Distribution characteristics and influencing factors of Heavy Metals in Pearl River Delta Quaternary Boreholes (in Chinese with English abstract). Adv. Earth Sci. 8, 885-898 (2017).

26. Liu, Z., Zhang, X. \& Luo, S. Lead isotopic composition of Quaternary sediments in Pearl River Delta and its significance (in Chinese with English abstract). Mod. Min. 27, 52-53 (2011).

27. Zhou, G. et al. Vertical distribution of trace elements in the sediment cores from major rivers in east China and its implication on geochemical background and anthropogenic effects. J. Geochem. Explor. 139, 53-67 (2014).

28. Sun, B., Zhou, G., Wei, H., Liu, Z. \& Zeng, D. The flux of river active material flowing into the sea: preliminary achievements (in Chinese with English abstract). Earth Sci. Front. 16, 361-368 (2009).

29. Callagon, E. et al. Heteroepitaxial growth of cadmium carbonate at dolomite and calcite surfaces: mechanisms and rates. Geochim. Cosmochim. Acta 205, 360-380 (2017).

30. Chiarello, R. et al. Otavite-calcite solid-solution formation at the calcite-water interface studied in situ by synchrotron X-ray sacttering. Geochim. Cosmochim. Acta 61, 1467-1474 (1997).

31. Jiang, Z., Lian, Y. \& Qin, X. Rocky desertification in southwest China: impacts, causes, and restoration. Earth Sci. Rev. 132, 1-12 (2014).

32. Jia, Z. et al. Identification of the sources and influencing factors of potentially toxic elements accumulation in the soil from a typical karst region in Guangxi, Southwest China. Environ. Pollut. 256, 1-9 (2020). 
33. Baize, D. \& Sterckeman, T. Of the necessity of knowledge of the natural pedo-geochemical background content in the evaluation of the contamination of soils by trace elements. Sci. Total Environ. 264, 127-139 (2001).

34. Beygi, M. \& Jalali, M. Background levels of some trace elements in calcareous soils of the Hamedan Province, Iran. Catena 162, 303-316 (2018).

35. Quezada-Hinojosa, R., Föllmi, K. B., Verrecchia, E., Adatte, T. \& Matera, V. Speciation and multivariable analyses of geogenic cadmium in soils at Le Gurnigel, Swiss Jura Mountains. Catena 125, 10-32 (2015).

36. Li, Z., Xu, X., Zhu, J., Xu, C. \& Wang, K. Effects of lithology and geomorphology on sediment yield in karst mountainous catchments. Geomorphology 343, 119-128 (2019).

37. Zeng, F. et al. Assessment of multiple and interacting modes of soil loss in the karst critical zone, southwest China (SWC). Geomorphology 322, 97-106 (2018).

38. Blowes, D. W., Ptacek, C. J., Jambor, J. L. \& Weisener, C. G. The geochemistry of acid mine drainage. InTreatise on Geochemistry, V. 11.5 (Holland, H. D. \& Turekian, K. K. eds) 137-142 (Elsevier, Amsterdam, 2014).

39. Wang, L. et al. $\mathrm{U}-\mathrm{Pb}$ and Re-Os geochronology and geodynamic settting of the Dabaoshan polymetallic deposit, northern Guangdong Province, South China. Ore Geol. Rev. 43, 40-49 (2011).

40. Chen, S., Xie, L., Liao, J., Xiang, H. \& Fu, Q. Method of intensity discrimination judgment of soil erosion of Dabaoshan mining area in Guangdong (in Chinese with English abstract). Soil Water Conserv. China 11, 40-43 (2007).

41. Qu, L. et al. Distribution, fractionation, and contamination assessment of heavy metals in paddy soil related to acid mine drainage. Paddy Water Environ. 15, 553-562 (2017).

42. Zhang, X., Tang, L., Zhang, G. \& Wu, H. Heavy metal contamination in a typical mining town of a minority and mountain area, South China. Bull. Environ. Contam. Toxicol. 82, 31-38 (2009).

43. Zhuang, P., Zou, B., Li, N. \& Li, Z. Heavy metal contamination in soils and food crops around Dabaoshan mine in Guangdong, China: implication for human health. Environ. Geochem. Health 31, 707-715 (2009).

44. Li, R., Tang, C., Cao, Y., Jiang, T. \& Chen, J. The distribution and partitioning of trace metals ( $\mathrm{Pb}, \mathrm{Cd}, \mathrm{Cu}$, and $\mathrm{Zn})$ and metalloid (As) in the Beijiang River. Environ. Monit. Assess. 190, 399-414 (2018).

45. Su, W., Xu, Y., Fan, S. \& Fu, S. The distribution regularity and accumulation risk of heavy metals in water and soil along the Hengshi River in the Dabaoshan mining area, Guangdong Province (In Chinese with English abstract). Geol. Bull. China 33, 1231-1238 (2014).

46. Zhu, B., Chen, Y. \& Peng, J. Lead isotope geochemistry of the urban environment in the Pearl River Delta. Appl. Geochem. 16, 409-417 (2001).

47. Statistics Bureau of Guangdong Province and Guangdong survey team of National Bureau of Statistics. Guangdong statistical yearbook (2017) (China Statistics Press, Beijing, 2017).

48. Shi, H. The role of Hills and Terraces in the Formation of Pearl River Delta and Its Net River (In Chinese). Master Dissertation, Sun Yat-sen University, China (2002).

49. Li, M. et al. National multi-purpose regional geochemical survey in China. J. Geochem. Explor. 139, 21-30 (2014).

50. Walkley, A. \& Black, I. A. An examination of the Degtjareff method for determining soil organic matter, and a proposed modification of the chromic acid titration method. Soil Sci. 37, 29-38 (1934).

51. Ministry of Agriculture of the People's Republic of China. Determination of pH in Soil (NY/T 1377-2007) (China Agricultural Press, Beijing, 2007).

52. Tessier, A., Campbell, P. G. C. \& Blsson, M. Sequential extraction procedure for the speciation of particulate trace metals. Anal. Chem. 51(7), 844-851 (1979).

53. China Geological Survey. Technical Requirements for Sample Analysis of Regional Eco-geochemical Assessment (DD2005-03) (China Geological Survey, Beijing, 2005).

54. Aitchison, J. The Statistical Analysis of Compositional Data (Chapman and Hall, London, 1986).

55. Reimann, C. et al. The concept of compositional data analysis in practice-total major element concentrations in agricultural and grazing land soils of Europe. Sci. Total Environ. 426, 196-210 (2012).

56. Reimann, C., Filzmoser, P., Hron, K., Kynčlová, P. \& Garrett, R. G. A new method for correlation analysis of compositional (environmental) data-a worked example. Sci. Total Environ. 607-608, 965-971 (2017).

57. Buccianti, A. et al. Exploring topsoil geochemistry from the CoDA (Compositional data analysis) perspective: the multi-element data archive of the Campania Region (Southern Italy). J. Geochem. Explor. 159, 302-316 (2015).

58. Drew, L. J., Grunsky, E. C., Sutphin, D. M. \& Woodruff, L. G. Multivariate analysis of the geochemistry and mineralogy of soils along two continental-scale transects in North America. Sci. Total Environ. 409, 218-227 (2010).

59. Otero, N., Tolosana-Delgado, R., Soler, A., Pawlowsky-Glahn, V. \& Canals, A. Relative vs. absolute statistical analysis of compositions: a comparative study of surface waters of a Mediterranean river. Water Res. 39, 1404-1414 (2005).

60. Ding, X., Ye, S., Yuan, H. \& Krauss, K. Spatial distribution and ecological risk assessment of heavy metals in coastal surface sediments in the Hebei Province offshore area, Bohai Sea, China. Mar. Pollut. Bull. 131, 655-661 (2018).

61. Salmanighabeshi, S. et al. Long-term assessment of ecological risk from deposition of elemental pollutants in the vicinity of the industrial area of Puchuncavi-Ventanas, central Chile. Sci. Total Environ. 527-528, 335-343 (2015).

62. Sutherland, R. Bed sediment-associated trace metals in an urban stream, Oahu, Hawaii. Environ. Geol. 39, 611-627 (2000).

\section{Acknowledgements}

This research was financially supported by the National Key R\&D Program of China (Project No. 2017YFD0800304), the Natural Science Foundation of China (Project No. 41773019), and the China Geological Survey Project (Project No. 12120113002300). We gratefully acknowledge Yang Xiaoyan, Liu Zining, and Wei Ran for their contributions to sample collection and fieldwork.

\section{Author contributions}

Z.Y. and Q.H. designed the project framework. Q.H., T.Y. and K.L. conducted the field work and collected the soil samples. Y.Y. and L.D. provided the geochemical data about the surface and deep soils and help in the field work. Q.H. wrote the manuscript. Z.Y. revised the manuscript.

\section{Competing interests}

The authors declare no competing interests.

\section{Additional information}

Supplementary information is available for this paper at https://doi.org/10.1038/s41598-020-74490-2.

Correspondence and requests for materials should be addressed to Z.Y. 
Reprints and permissions information is available at www.nature.com/reprints.

Publisher's note Springer Nature remains neutral with regard to jurisdictional claims in published maps and institutional affiliations.

(c) (i) Open Access This article is licensed under a Creative Commons Attribution 4.0 International License, which permits use, sharing, adaptation, distribution and reproduction in any medium or format, as long as you give appropriate credit to the original author(s) and the source, provide a link to the Creative Commons licence, and indicate if changes were made. The images or other third party material in this article are included in the article's Creative Commons licence, unless indicated otherwise in a credit line to the material. If material is not included in the article's Creative Commons licence and your intended use is not permitted by statutory regulation or exceeds the permitted use, you will need to obtain permission directly from the copyright holder. To view a copy of this licence, visit http://creativecommons.org/licenses/by/4.0/.

(C) The Author(s) 2020 